УДК 378.02. (80:41)

DOI https://doi.org/10.24919/2308-4863/34-1-37

Bima БОCA,
orcid.org/0000-0001-7509-7044
кандидат педагогічних наук,

доцент кафедри романської філологї та порівняльно-типологічного мовознавства

Інституту філологї

Київського університету імені Бориса Грінченка

(Київ, Україна) vitta.fabian2000@gmail.com

\title{
ІНФОРМОЛОГІЯ ЯК МЕТОДОЛОГІЧНА ОСНОВА ПІДГОТОВКИ СУЧАСНОГО ФАХІВЦЯ-ФІЛОЛОГА
}

\begin{abstract}
У статті з 'ясовано сутність і специфіку використання інформологічного підходу до професійної підготовки фахівців-філологів у сучасному університеті. Визначено провідні завдання інформологічного аналізу проблеми професійної підготовки фахівців-філологів в університеті в контексті визначення методологічних ресурсів інформології як науки про інформацію та ії основні види. Окреслено стан і перспективи наукових досліджень у сфері педагогічної інформології та педагогічної семіотики щцодо інформологічного забезпечення підготовки студентів-філологів. Представлено науковий тезаурус педагогічної інформології в єдності категорії інформації та базових понять - інформологічної діяльності, інформологічної компетентності, знака і символа. Обтрунтовано можливості інформаційно-технологічного забезпечення прочесу професійної підготовки майбутніх філологів із використанням різних видів інформації (звукової, текстової, числової, графічної, аудіальної, візуальної, масової, спеціальної, особистої) у ї̈ структурованому та неструктурованому вигляді. Сформульовано висновок про триєдине значення мови як об'єднуючого чинника для педагогічної інформології (як науки про педагогічні ресурси всіх видів інформації, щзо використовується в навчальному процесі), педагогічної семіотики (науки про знаковосимвольну систему педагогічної діяльності) і теорії та практики професійної підготовки майбутніх філологів в університеті. Схарактеризовано педагогічні ресурси неструктурованих (друкованих джерел інформації) та структурованих видів інформаційно-комунікаційних технологій (мультимедійних засобів навчання; хмаро орієнтованих технологій; електронних словників, підручників та іншої навчально-методичної літератури; електронних баз даних; систем комп 'ютерного тестування студентів) у професійній підготовці фахівців-філологів. Сформульовано висновок про методологічну та прикладну (методичну) функцію педагогічної семіотики. Інформаційні технологї̈ професійної підготовки фахівців представлено в єдності програмної й апаратної складових частин; наголочено на ролі сучасних інформаційних технологій у традиційному (офлайновому) та дистанційному (онлайновому) прочесі професійної підготовки філологів.
\end{abstract}

Ключові слова: інформація, інформологія, семіотика, інформаційно-комунікаційні технологї, фахівці-філологи.

Vita BOSA, orcid.org/0000-0001-7509-7044 Candidate of Pedagogical Sciences, Associate Professor at the Department of Romance Philology and Comparative-typological Linguistics

Institute of Philology

of Borys Grinchenko Kyiv University (Kyiv, Ukraine) vitta.fabian2000@gmail.com

\section{INFORMATION SCIENCE AS A METHODOLOGICAL BASIS FOR THE TRAINING OF A CONTEMPORARY SPECIALIST-PHILOLOGISTS}

The article discusses the essence and specificity of the use of the informational approach to the training of specialistsphilologists at the modern university. The main tasks of informational analysis of the problem of training of specialistsphilologists at the university in the context of the definition of methodological resources information science as a science of information and its main types have been defined. The status and prospects of scientific research in the field of pedagogical information and pedagogical semiotics on the informational provision of the training of students-philologists have been determined. The scientific thesaurus of pedagogical information is presented in unity of information category and basic concepts - informational activity, informatiological competence, sign and symbol. Justified possibilities of information technology support of the process of training of future philologists using different types of information (sound, text, numerical, graphic, audible, visual, mass, special, personal) in its structured and unstructured form. Conclusion on the triple meaning of language as a unifying factor for pedagogical information (as a science about pedagogical resources 
of all types of information used in the educational process), pedagogical semiotics (the sciences of the iconic system of pedagogical activity) and the theory and practice of professional training of future philologists at the university. Pedagogical resources of unstructured (printed information sources) and structured (multimedia learning tools; clouds of targeted technologies; electronic dictionaries, textbooks and other teaching materials; electronic databases, student computer testing systems) Information and communication technologies in the training of professional and philologists. A conclusion has been drawn on the methodological and applied (methodical) function of pedagogical semiotics. Information technology for professional training is presented in a single software and hardware component; noted as modern information technology in the traditional (offline) and remote (online) process The process of training philologists.

Key words: information, information, semiotics, information and communication technologies, philologists.

Постановка проблеми. Професійна підготовка сучасного фахівця за умов університету передбачає використання системи сучасних інформаційних технологій 3 огляду на специфіку змісту означеної підготовки, необхідність їі реформування з урахуванням розвитку сучасного інформаційного простору науки та інформаційного середовища кожного 3 напрямів підготовки, а також співвідношення офлайнових та онлайнових сегментів професійної підготовки фахівців 3 огляду на глобальні пандемічні кризи, що визначають особливості теорії та методики професійної освіти в Україні та світі. Професійна діяльність фахівця-філолога постійно перебуває у просторі рідномовної та іншомовної взаємодії, сутність якої полягає в обміні, накопиченні, передачі інформації у вигляді ідей, думок, рішень, даних; означена взаємодія, таким чином, має виражений інформологічний характер. У зв'язку з цим постає проблема системного аналізу можливостей сучасних інформаційних технологій у забезпеченні якісної професійної підготовки студентів-філологів в університетах України із застосуванням ресурсів реального та віртуального інформаційного простору, яким може диспонувати заклад вищої освіти та його основні стейкхолдери.

Аналіз досліджень. Інформологія як наука про інформацію перебуває в полі наукових інтересів переважно представників сучасної інформатики й освітніх технологій у розумінні сучасних IКT. У вітчизняну науку цей термін введено у 80-ті pp. $\mathrm{XX}$ ст.; найбільш значущі наукові розвідки в інформології належать М. Жалдаку, Н. Морзе, О. Спіріну, Т. Вакалюк та ін. Можливості використання різних типів і видів інформаційних технологій у підготовиі фахівців подано в наукових публікаціях І. Богданової, Н. Баліцької, О. Біди, В. Кузя, Л. Пироженко, Т. Дуткевич та ін. Інноваційний характер сучасних інформаційних технологій у закладах вищої освіти частково представлено в дослідженнях В. Докучаєвої, О. Дуплійчук, О. Сльникової та ін.

Щодо професійної підготовки філологів, то iii інформологічні засади більшою чи меншою мірою висвітлені в публікаціях I. Бакаленко,
О. Липчанко-Ковачик, Л. Морської, Л. Тополі та ін. Окремі наукові праці репрезентують методологічний аспект проблеми нашого дослідження це роботи В. Гури (культурологічні засади використання сучасних IКТ у навчальному процесі), М. Коляди (можливості використання діяльнісного підходу у формуванні інформаційної культури фахівця), Л. Тишакової (компетентнісні засади підготовки вчителя-філолога у ЗВО), В. Шуляр (акмеологічні основи підготовки вчителя-філолога в системі післядипломної освіти) та ін.

На підставі аналізу наукових публікацій із проблеми дослідження можемо констатувати, що переважна іх більшість стосується професійної підготовки вчителів-словесників у різноманітних аспектах цього педагогічного процесу (використання різних форм інтерактивного навчання iз застосуванням IКТ, загальної характеристики інформаційних технологій у підготовці вчителясловесника, формування професійної компетентності вчителя-філолога засобами ІКТ тощо). Крім того, дослідницький ракурс у переважній більшості проаналізованих праць зосереджено на інтерактивних технологіях навчання, які передбачають використання інформаційних технологій як дидактичного засобу. Натомість грунтовне вивчення методологічних засад використання сучасних інформаційних технологій у підготовці фахівця-філолога представлене в педагогічній науці досить фрагментарно, тому потребує формування належної методологічної бази та системних експериментальних результатів.

У зв'язку з цим метою статті нами визначено аналіз ролі та місця інформології як методологічної основи професійної підготовки філологів в університеті.

Виклад основного матеріалу. Як свідчить проаналізована нами у процесі дослідження вітчизняна та зарубіжна словниково-довідникова література («Енциклопедія бібліотечних та інформаційних наук», 2005; «Великий тлумачний словник сучасної української мови», 2005), інформологію окреслюють переважно як узагальнене поняття, котре дефініює всі науки про інформацію, притаманні сучасному науковому простору. 
Специфіка цієї галузі знання полягає в аналізі (на методологічному, теоретичному та прикладному рівні) й описі процесів передачі інформації в комунікативному, інформатичному, технологічному, професійно-педагогічному контекстах. Зарубіжні науковці, зокрема Б. Брукс (Brookes, 1980), визначають інформологію як галузь філософії, оскільки інформацію відносять до загальних філософських категорій. Як наука про інформацію інформологія на початку свого існування стосувалася переважно документознавства, однак згодом стала використовуватися у різних галузях, які виокремлюють інформацію як об'єктивний атрибут функціонування наукового знання. Російський учений А. Урсул (Урсул, 1990) визначив інформологію як науку про форми руху матерії в неживій і живій природі, а також у суспільних організмах. У цій науковій сфері можна визначити як метанауковий i методологічний, так і прикладний рівень залежно від завдань, що ставляться перед дослідником, i від характеру інформації, яка використовується для вирішення цих завдань. Методологічними можливостями інформології користуються як суто інформаційно-технічні (кібернетика, інформатика), так і гуманітарні науки (як-от семіотика, синергетика тощо). У площині педагогічних наук, на нашу думку, є сенс говорити про педагогічну інформологію, котру можемо окреслити як науку про педагогічну інформацію та відповідні процеси, що тї супроводжують - накопичення, обмін, створення, передачу тощо. Відповідно, педагогічна інформологія вирізняється із загальної інформологічної науки змістом інформації, що функціонує в педагогічному просторі та має педа- гогічні характеристики - дидактичні, пізнавальні, мотиваційні, технологічні, процесуальні та ін. У науковому дослідженні В. Шакотько (Шакотько, 2017) розглядається також поняття інформологічної компетентності як сукупності відповідних інформологічних знань, вмінь і навичок використовувати інформацію в навчальному процесі, особистісних якостей, які забезпечують необхідний рівень інформологічної діяльності. Таким чином, до наукового тезаурусу педагогічної інформології можемо віднести:

1) категоріюінформаціїякбазову дляпедагогічної інформології, що визначає знаково-символьні характеристики професійної підготовки фахівців;

2) поняття інфомологічної компетентності як результату інформаційно-технологічної підготовки студентів;

3) поняття інформологічної діяльності як різновиду навчальної та квазіпрофесійної діяльності, що визначає здатність майбутніх фахівців працювати з різними видами інформації;

4) поняття знака і символа як семіотичного відображення інформації, притаманної професійній підготовці фахівців.

Перший компонент означеного тезаурусу інформацію-ми розуміємо як глобальний феномен, притаманний фактично всім наукам. Інформологія розглядає і вивчає різноманітні види інформації; частина 3 них безпосередньо стосуються створення i розвитку сучасних інформаційних технологій у ЗВО, інша частина - безпосередньо підготовки фахівців, у нашому випадку - майбутніх філологів. Так, виділяють різні види інформації за кількома критеріями поділу (за М. Козир, 2015):

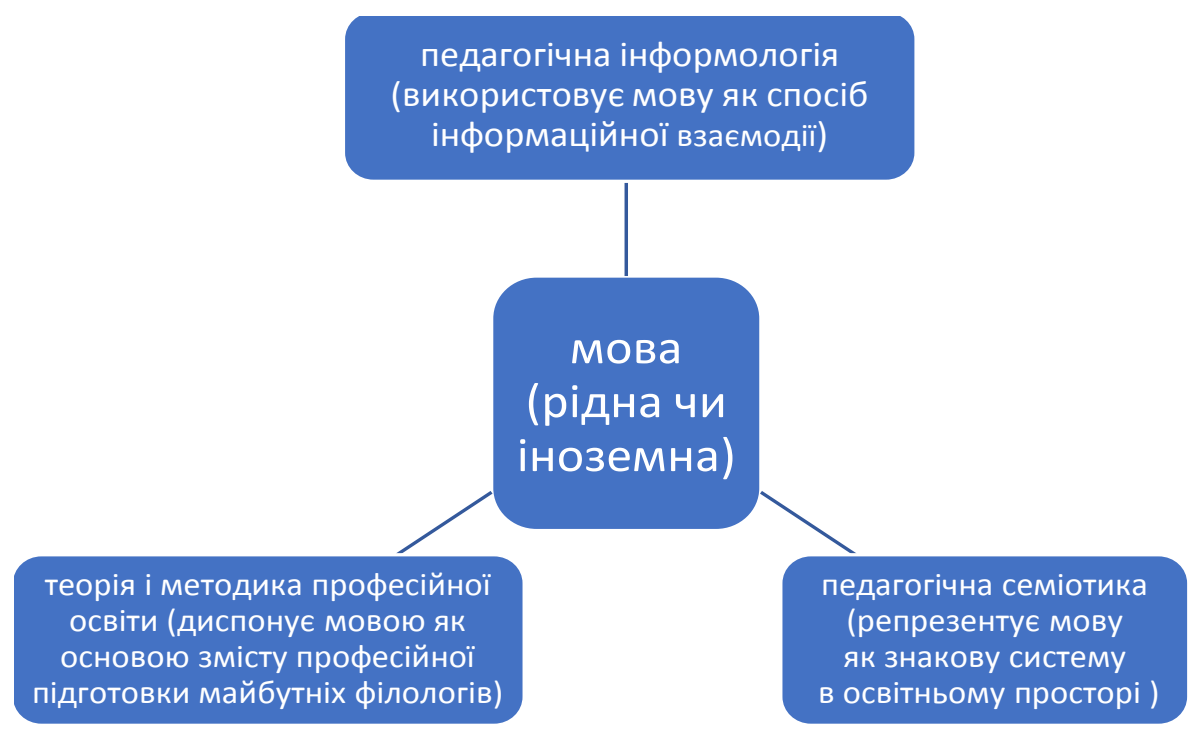

Рис. 1. Мова як об'сднуючий чинник у трисдності педагогічної інформології, педагогічної семіотики та професійної підготовки майбутніх філологів 
1) за способом відображення - звукову, текстову, числову, графічну, комбіновану;

2) за призначенням - масову, спеціальну, особисту;

3) за способом сприйняття - візуальну, аудіальну, тактильну, нюхову, смакову.

Найчастіше інформаційний простір професійної підготовки майбутніх фахівців ототожнюють із інформаційно-комунікачійними технологіями. Якщо йдеться про напрям підготовки 035 «Філологія», то таке звуження тезаурусу є цілком виправданим, оскільки професійна підготовка і майбутня професійна діяльність філолога пов'язана передовсім із комунікативними процесами у їх інформологічному контексті, а мова служить основним знаковим інструментом і підготовки фахівців, i предметною площиною їхньої професійної діяльності. Традиційно до сучасних IКТ у професійній педагогіці відносять апаратну і програмну складові частини (за Г. Дегтярьовою, 2016), а саме:

1) технічні засоби (різноманітну комп'ютерну техніку, гаджети, мультимедійні проектори, інтерактивні дошки, сканери, принтери, аудіотехніку тощо);

2) програмне забезпечення (пакети прикладних (наприклад, словниково-довідникових чи перекладацьких) програм, браузери);

3) ресурси мережі Інтернет, у т. ч. мережеві сервіси та хмаро орієнтовані технології, зокрема спеціально створені для підготовки фахівців напряму «Філологія».

Інформаційно-технологічне забезпечення процесу професійної підготовки майбутніх філологів із використанням різних видів інформації

\begin{tabular}{|c|c|c|}
\hline $\begin{array}{c}\text { Вид } \\
\text { інформації }\end{array}$ & $\begin{array}{c}\text { Сутність і специфіка використання у } \\
\text { професійній підготовці філологів }\end{array}$ & $\begin{array}{c}\text { Інформаційно-технологічне та інформаційно- } \\
\text { комунікаційне забезпечення процесу } \\
\text { використання цього виду інформації }\end{array}$ \\
\hline $\begin{array}{l}\text { Звукова, } \\
\text { текстова, } \\
\text { числова, } \\
\text { графічна }\end{array}$ & $\begin{array}{l}\text { Означені види інформації представлені у } \\
\text { процесі професійної підготовки філологів } \\
\text { у структурованому (джерела інформації, } \\
\text { що мають попередньо задані тип, форму, } \\
\text { розмір тощо) та неструктурованому } \\
\text { вигляді (традиційні текстові, звукові, гра- } \\
\text { фічні документи). }\end{array}$ & $\begin{array}{l}\text { У професійній підготовці фахівців-філологів обидва } \\
\text { варіанти інформації (структурований і неструктурова- } \\
\text { ний) мають важливе значення. Так, до неструктурова- } \\
\text { них видів інформації традиційно відносять друковані } \\
\text { джерела інформації (підручники, посібники, наукові } \\
\text { збірники, словниково-довідникову літературу та ін., } \\
\text { що належать галузі філологічної науки). До структу- } \\
\text { рованих інформаційних даних відносять переважно } \\
\text { новітні інформаційні джерела та програмні продукти } \\
\text { (мультимедійні технології та засоби навчання; інфор- } \\
\text { мацію, що використовується за допомогою хмаро } \\
\text { орієнтованих технологій; електронні словники, під- } \\
\text { ручники та іншу навчально-методичну літературу; } \\
\text { електронні бази даних; системи компюютерного тес- } \\
\text { тування студентів та ін.) }\end{array}$ \\
\hline $\begin{array}{l}\text { Масова, } \\
\text { спеціальна, } \\
\text { особиста }\end{array}$ & $\begin{array}{l}\text { Такий поділ інформації на види спри- } \\
\text { чинений суб'єктними характеристи- } \\
\text { ками інформації, що використовується в } \\
\text { навчальному процесі. Так, масова інфор- } \\
\text { мація має найбільш загальний характер; у } \\
\text { процесі вивчення фахових дисциплін важ- } \\
\text { ливе місце займає спеціальна інформація, } \\
\text { а загалом у процесі їі сприйняття просте- } \\
\text { жується особистісний характер засвоєння } \\
\text { та інтерпретації навчальної інформації } \\
\text { кожним студентом }\end{array}$ & $\begin{array}{l}\text { Названі види інформації реалізуються у процесі } \\
\text { застосування як традиційних, так і інноваційних } \\
\text { форм і методів професійної підготовки майбутніх } \\
\text { філологів і формування їхньої професійної компе- } \\
\text { тентності (лекцій, практичних і семінарських занять, } \\
\text { лабораторних занять, всіх видів виробничих прак- } \\
\text { тик, оцінки результатів навчальної діяльності, під- } \\
\text { сумкових атестацій тощо). Реалізація названих форм } \\
\text { навчальної діяльності може відбуватися як у режимі } \\
\text { оff-line (переважно із застосуванням неструктурова- } \\
\text { ної інформації), так і оп-line (переважно з викорис- } \\
\text { танням структурованої інформації) }\end{array}$ \\
\hline $\begin{array}{l}\text { Аудіальна, } \\
\text { візуальна }\end{array}$ & $\begin{array}{l}\text { Ці два види інформації представляють } \\
\text { специфіку ії чуттєвого сприйняття і пере- } \\
\text { бувають у постійному взаємозв'язку. } \\
\text { Домінація слухового чи зорового відчуття } \\
\text { впливає на співвідношення сенсорних } \\
\text { модальностей студента, що безпосеред- } \\
\text { ньо визначає ефективність процесу засво- } \\
\text { єння, інтерпретацї̈, відтворення навчаль- } \\
\text { ної інформації майбутніми філологами } \\
\end{array}$ & $\begin{array}{l}\text { Аудіальні та візуальні дидактичні засоби навчання } \\
\text { утворюють комплекс технологічних засобів - як } \\
\text { традиційних (діалогічних засобів навчання, суб’єкт- } \\
\text { суб’єктних навчальних комунікацій тощо), так і } \\
\text { інноваційних (аудіо- та візуальних комп’ютерних } \\
\text { тренажерів, лінгафонних кабінетів, мультимедійних } \\
\text { аудіо- та візуальних навчальних засобів та ін.) }\end{array}$ \\
\hline
\end{tabular}

Джерело: розроблено автором 
Щодо знакової системи педагогічної інформології, то ії вивченням займається семіотика, причому науковці виділяють також педагогічну семіотику, предметом дослідження якої $є$ знакова система процесу навчання і виховання на різних ступенях освіти. Таким чином, педагогічна семіотика та педагогічна інформологія тісно пов'язані між собою спільною знаковою системою - мовою. Ця знакова система має вирішальне значення у професійній підготовці філологів за умов університету. Тому мовну знакову систему можна вважати триєдиним феноменом, який об'єднує педагогічну інформологію, педагогічну семіотику i, власне, теорію та практику професійної підготовки філологів як дослідницьку проблему, як це представлено на рис. 1.

Семіотика у професійній підготовці майбутніх філологів виконує і методологічну, і прикладну методичну функцію. Так, у методологічному відношенні семіотика відображає сукупність теоретичних підходів до аналізу феномену комунікації; у прикладному - репрезентує аналіз мовного контенту, притаманного професійній підготовці філологів: текстів, знаків, символів, дискурсу тощо (Ковтуненко, 2013). В інформологічному контексті семіотика може бути використана як інструмент конструювання знакових систем і знакових ситуацій комунікативного характеру, що розробляються в межах сучасних інформаційно-комунікаційних технологій.

Як свідчить проаналізована нами наукова література та власний досвід науково-педагогічної діяльності, у процесі професійної підготовки майбутніх філологів використовуються майже всі види інформації, що несуть семіотичне й суто педагогічне навантаження. Сучасне інформаційно-технологічне забезпечення процесу використання різних видів інформації у підготовці філологів у ЗВО ми відобразили в табл. 1 .

Всі представлені в табл. 1 види інформації в сукупності утворюють систему; крім цього, системними характеристиками наділені й інші процеси, явища й об'єкти, котрі характеризують професійну підготовку філологів за умов сучасного університету. В інформології широко використовується поняття «інформачійна система», методологічно близьке до проблеми інформаційно-технологічного забезпечення професійної підготовки філологів у кількох аспектах:

- у системному характері інформаційних технологій, який реалізуються у процесі професійної підготовки філологів;
- в аспекті системи комунікацій, що становлять основу організаційно-педагогічних умов професійної підготовки названих фахівців;

- в окресленні педагогічної технології, яка реалізується в ході підготовки фахівців, як системного явища.

Інформаційна система підготовки філологів за умов університету може розглядатися в широкому та вузькому розумінні. Означена система у загальному (широкому) контексті окреслюється як простір, де відбуваються найзагальніші інформаційні процеси (пошук, збирання, обмін, зберігання, передача інформації). У вузькому розумінні інформаційна система підготовки фахівців-філологів в університеті $\epsilon$ комплексом спеціально розроблених технічних, програмних (як організаційних, так і дидактичних) засобів, що забезпечують всі інформаційні процеси.

Висновки. Таким чином, нами 3'ясовано сутність і специфіку використання інформологічного підходу до професійної підготовки фахівців-філологів у сучасному університеті. Окреслено стан і перспективи наукових досліджень у сфері педагогічної інформології та педагогічної семіотики щодо інформологічного забезпечення підготовки студентів-філологів; представлено науковий тезаурус педагогічної інформології. Обгрунтовано можливості інформаційно-технологічного забезпечення процесу професійної підготовки майбутніх філологів із використанням різних видів інформації (звукової, текстової, числової, графічної) у ii структурованому та неструктурованому вигляді. Сформульовано висновок про триєдине значення мови як об'єднуючого чинника для педагогічної інформології, педагогічної семіотики, теорії та практики професійної підготовки майбутніх філологів в університеті. Інформаційні технології професійної підготовки фахівців представлено в єдності програмної та апаратної складових частин; наголошено на ролі сучасних інформаційних технологій у процесі традиційного (офлайнового) та дистанційного (онлайнового) процесу професійної підготовки філологів. Перспективи наших подальших досліджень вбачаємо в обгрунтуванні системного та компетентнісного підходів до професійної підготовки майбутніх філологів засобами сучасних інформаційно-комунікаційних технологій в університеті. 


\section{СПИСОК ВИКОРИСТАНИХ ДЖЕРЕЛ}

1. Encyclopedia of Library' and Information Science/M.A. Drake. BocaRaton, London, NY, Singapore:TaylorandFrancis, 2005. $418 \mathrm{p}$.

2. Великий тлумачний словник сучасної української мови / укл. і гол. ред. В.Г.Бусел. Київ - Ірпінь : Перун. 2005. 1728 c.

3. Brookes B. C. The foundations of information science. Part 1. Philosophical aspects. Journal of information science. 1980. № 2. Р. 125-133.

4. Урсул А. Д. Социальная информатика: две концепции развития. НТИ. ВИНИТИ. Серия 1.1990. № 1. С. 3-5.

5. Шакотько В. В. Інформологія в педагогічному університеті та школі: електронний посібник. 2017. URL: https://sites.google.com/view/i-informology.

6. Козир М. В. Інформаційна педагогіка як розділ прикладної інформології. Освітологічний дискурс. 2015. C. 141-149.

7. Дегтярьова Г. А. Засоби інформаційно-комунікаційних технологій для розвитку ІК-компетентності вчителів філологічних дисциплін. Інформаційні технологї̈ і засоби навчання. 2016. Т. 56. № 6. С. 107-120.

8. Ковтуненко Е. С. Методологічні підходи в семіотичному аналізі. Наукові праці Чорноморського державного університету імені Петра Могили. Серія Соціологія. 2013. Т. 211. Вип. 199. С. 44-48.

\section{REFERENCES}

1. Encyclopedia of Library' and Information Science / M. A. Drake. Boca Raton, London, NY, Singapore: Taylor and Francis, 2005. 418 c. [in English]

2. Velykyi tlumachnyi slovnyk suchasnoi ukrainskoi movy [Great Dictionary of the modern Ukrainian language]. Ukl. ihol.red. V.H.Busel. Kyiv: Irpin, Perun. 2005. 1728 s.[ in Ukrainian]

3. Brookes B. C. The foundations of information science. Part 1. Philosophical aspects. Journal of information science. 1980. № 2. P. 125-133. [in English]

4. Ursul A. D. Sotsyalna informatyka: dve kontseptsyy razvytyia [Social informatics: two concepts of development]. NTY. VYNYTY. Seryia 1. 1990. № 1. S. 3-5. [in Russian]

5. Shakotko V. V. Informolohiia $\mathrm{v}$ pedahohichnomu universyteti ta shkoli: elektronnyi posibnyk [Informology in pedagogical university and school: electronic manual]. 2017. URL: https://sites.google.com/view/i-informology.[in Ukrainian]

6. Kozyr M. V. Informatsiina pedahohika yak rozdil prykladnoi informolohii [Information pedagogy as a section of applied informology]. Osvitolohichnyi dyskurs. 2015. № 2. S. 141-149.[in Ukrainian]

7. Dehtiarova H. A. Zasoby informatsiino-komunikatsiinykh tekhnolohii dlia rozvytku IK-kompetentnosti vchyteliv filolohichnykh dystsyplin [Means of information and communication technologies for the development of IR competence of teachers of philological disciplines]. Informatsiini tekhnolohii i zasoby navchannia. 2016. T. 56. № 6. S. 107-120. [in Ukrainian]

8. Kovtunenko E. S. Metodolohichni pidkhody v semiotychnomu analizi [Methodological approaches in semiotic analysis]. Naukovi pratsi Chornomorskoho derzhavnoho universytetu imeni Petra Mohyly. Seriia Sotsiolohiia. 2013. T. 211. Vyp. 199. S. 44-48. [in Ukrainian] 